\title{
Platelet-rich plasma: why intra-articular? A systematic review of preclinical studies and clinical evidence on PRP for joint degeneration
}

\author{
G. Filardo $\cdot$ E. Kon $\cdot$ A. Roffi $\cdot$ B. Di Matteo $\cdot$ \\ M. L. Merli • M. Marcacci
}

Received: 30 August 2013/ Accepted: 22 October 2013/Published online: 26 November 2013

(c) The Author(s) 2013. This article is published with open access at Springerlink.com

\begin{abstract}
Purpose The aim of this review was to analyze the available evidence on the clinical application of this biological approach for the injective treatment of cartilage lesions and joint degeneration, together with preclinical studies to support the rationale for the use of platelet concentrates, to shed some light and give indications on what to treat and what to expect from intra-articular injections of platelet-rich plasma (PRP).

Methods All in vitro, in vivo preclinical and clinical studies on PRP injective treatment in the English language concerning the effect of PRP on cartilage, synovial tissue, menisci, and mesenchymal stem cells were considered. A systematic review on the PubMed database was performed using the following words: (platelet-rich plasma or PRP or platelet concentrate or platelet lysate or platelet supernatant) and (cartilage or chondrocytes or synoviocytes or menisci or mesenchymal stem cells).

Results Fifty-nine articles met the inclusion criteria: 26 were in vitro, 9 were in vivo, 2 were both in vivo and in vitro, and 22 were clinical studies. The analysis showed an increasing number of published studies over time. Preclinical evidence supports the use of PRP injections that might promote a favourable environment for joint tissues
\end{abstract}

\footnotetext{
G. Filardo · E. Kon · A. Roffi

Nano-Biotechnology Laboratory, II Orthopaedic Clinic, Rizzoli Orthopaedic Insitute, Via di Barbiano n. 1/10, 40136 Bologna, Italy

G. Filardo $\cdot$ E. Kon $\cdot$ B. Di Matteo $(\bowtie)$.

M. L. Merli · M. Marcacci

Biomechanics Laboratory, II Orthopaedic Clinic, Rizzoli Orthopaedic Insitute, Via di Barbiano n. 1/10, 40136 Bologna, Italy

e-mail: berardo.dimatteo@gmail.com
}

healing. Only a few high-quality clinical trials have been published, which showed a clinical improvement limited over time and mainly documented in younger patients not affected by advanced knee degeneration.

Conclusions Besides the limits and sometimes controversial findings, the preclinical literature shows an overall support toward this PRP application. An intra-articular injection does not just target cartilage; instead, PRP might influence the entire joint environment, leading to a shortterm clinical improvement. Many biological variables might influence the clinical outcome and have to be studied to optimize PRP injective treatment of cartilage degeneration and osteoarthritis.

Level of evidence IV.

Keywords PRP · Growth factors - Knee · Intra-articular · Injection · Cartilage

\section{Introduction}

A healthy joint requires a fine-tuned balance between molecular signals regulating homeostasis, damage, restoration, and remodelling. This balance is determined both at the level of single cells and the whole tissue architecture, and it also involves interactions among different tissues such as cartilage, bone, synovium, ligaments, tendons, and menisci [46]. Different factors are able to impair the maintenance of homeostasis in a joint that has been damaged or strained, and they may progressively lead to osteoarthritis (OA) [27, 29].

A wide spectrum of treatments is available, from nonpharmacological modalities to dietary supplements and pharmacological therapies, as well as minimally invasive procedures involving injections of various substances 
aimed at restoring joint homeostasis and providing clinical improvement and, possibly, a disease-modifying effect [39]. When these treatments fail, more invasive surgical approaches can be attempted to avoid metal resurfacing through the restoration of the mechanical balance and the regeneration of the articular surface, although results are still controversial [21, 22]. Even though some of these approaches have been shown to offer a satisfactory clinical outcome at midterm follow-up, rehabilitation is long and results are often unpredictable, incomplete, and limited over time [10, 15, 16, 18, 37].

The search for a minimally invasive solution to improve the status of the joint surface and allow a fast return to full activity is therefore highly desirable. In this landscape, a novel promising injective treatment is platelet-rich plasma (PRP), a blood derivative that has a higher platelet concentrate than whole blood. When activated, platelets release a group of biologically active proteins that bind to the transmembrane receptors of their target cells, thus leading to the expression of gene sequences that ultimately promote cellular recruitment, growth, and morphogenesis, and modulating inflammation as well [3]. Therefore, PRP represents an appealing biological approach to favour the healing of tissues otherwise doomed by a low healing potential, such as cartilage. This led to the wide use of PRP, which shows promising results as a minimally invasive injective treatment of cartilage degeneration and OA, both in preclinical and clinical studies [40, 67]. However, besides the increasing interest both among physicians and the scientific community, results are sometimes contradictory with no clear treatment indications, due to lowlevel clinical studies and the lack of understanding on the mechanism of action of this blood derivative [40].

The aim of this review was to analyze systematically the available evidence on the clinical application of this biological approach for the injective treatment of cartilage lesions and joint degeneration, together with preclinical studies to support the rationale for this use of platelet concentrates, to shed some light and give indications on what to treat and what to expect from intra-articular injections of PRP.

\section{Materials and methods}

All in vitro, in vivo preclinical and clinical studies on PRP injective treatment in the English language concerning the effect of PRP on cartilage, synovial tissue, and menisci were considered. Since PRP injections could be used as augmentation procedure after bone marrow stimulation techniques or other cell type transplantations, the analysis of studies dealing with the PRP effect on mesenchymal stem cells (MSCs) of various origins for cartilage treatment was also included. A systematic review on the PubMed database was performed using the following words: (Platelet-Rich Plasma OR PRP OR Platelet Concentrate OR Platelet Lysate OR Platelet Supernatant) AND (Cartilage OR Chondrocytes OR synoviocytes OR menisci OR mesenchymal stem cells). Reference lists from the selected papers were also screened. Relevant data were then extracted and collected in three tables, separating in vitro, in vivo preclinical studies, and clinical studies (case reports were not considered) (Tables 1, 2, 3). Two studies focused on in vitro and preclinical in vivo evaluations and were reported in both Tables 1 and 2. The in vitro studies were divided according to the cell population targeted. With regard to clinical trials, only comparative and randomized controlled trials (RCTs) were discussed further in the present manuscript.

\section{Results}

According to the search strategy, 388 papers were screened, among these 59 met the inclusion criteria: 26 were in vitro, 9 were in vivo, 2 were both in vivo and in vitro, and 22 were clinical studies. The analysis of per year publication showed increasing interest in this topic with an increasing number of published studies over time, in particular with regard to reports documenting results of the clinical injective application of PRP (Fig. 1).

\section{In vitro studies}

\section{Chondrocytes}

Seventeen papers investigated the effect of PRP on chondrocytes (Table 1) [1, 5, 11, 19, 28, 33, 44, 48, 54, 57, 59, $61,69,73,75-77]$. In particular, 13 papers reported an increase in chondrocyte proliferation rate. Muraglia et al. [54] even showed that PRP promoted cell proliferation in conditions where fetal calf serum (FCS) had no proliferation stimulating effect, as in chondrocytes from elderly patients. Four papers by Drengk et al. [11], Gaissmaner et al. [19], Kaps et al. [33], and Yang et al. [76] observed, together with the increase in cell proliferation, an inhibition of chondrogenic markers expression. Conversely, 10 papers reported an increase in chondrocyte proliferation rate without affecting chondrogenic phenotype maintenance. Hildner et al. [28] even documented that proliferation and chondrogenic redifferentiation potential were higher when human articular chondrocytes were previously expanded with platelet lysate (PL) instead of FCS. Besides the overall proliferation increase with phenotype maintenance, Park et al. [57] underlined another key point: the 
Table 1 In vitro studies

\begin{tabular}{|c|c|c|}
\hline Publications & PRP characteristics & PRP effects \\
\hline \multicolumn{3}{|l|}{ Chondrocytes } \\
\hline Yin [77] & $\begin{array}{l}\text { Platelet count: } 2,604 \pm 602 \times 10^{3} / \mathrm{ml} \\
\text { Activation: - } \\
\text { No leukocytes }\end{array}$ & $\begin{array}{l}\text { Increase in proliferation and ECM deposition in the integration area between } \\
\text { agarose scaffold and cartilage samples } \\
\text { Higher scaffold integration strength }\end{array}$ \\
\hline Muraglia [54] & $\begin{array}{l}\text { Platelet count: } 10 \times 10^{6} / \mu 1 \\
\text { No activation } \\
\text { Leukocytes: - }\end{array}$ & $\begin{array}{l}\text { Increase in cell proliferation more than FCS, also in chondrocytes from elderly } \\
\text { patients }\end{array}$ \\
\hline Hildner [28] & $\begin{array}{l}\text { Platelet count: - } \\
\text { Activation: - } \\
\text { Leukocytes: - }\end{array}$ & $\begin{array}{l}\text { Increase in proliferation } \\
\text { Better redifferentiation potential than FCS expanded cells }\end{array}$ \\
\hline Park [57] & $\begin{array}{l}\text { Platelet count: } 6-10 \times 10^{6} / \mu 1 \\
\text { No activation } \\
\text { Leukocytes: - }\end{array}$ & $\begin{array}{l}\text { Dose-dependent increase in chondrocytes proliferation maintained at } 4 \text { days in } \\
5,10,20 \% \text { PRP } \\
\text { Chondrogenic phenotype maintenance } \\
\text { Time-dependent increase in angiogenic and antiangiogenic factors expression } \\
\text { (VEGF, ChM-I) }\end{array}$ \\
\hline Lee [44] & $\begin{array}{l}\text { Platelet count: - } \\
\text { Activation: - } \\
\text { No leukocytes }\end{array}$ & $\begin{array}{l}\text { Increased chondrocyte proliferation in time-dependent manner } \\
\text { Enhanced hydrogel scaffold-chondrocyte maturation } \\
\text { Immediate increase in CB1 and CB2 mRNA expression }\end{array}$ \\
\hline Pereira [59] & $\begin{array}{l}\text { Platelet count: } 1 \times 10^{7} / \mathrm{ml} \\
\text { Activation: freezing and thawing } \\
\text { Leukocytes: - }\end{array}$ & $\begin{array}{l}\text { Increase in cell proliferation } \\
\text { Chondrogenic phenotype maintenance but decrease over time in micromass } \\
\text { pellet cultures } \\
\text { Initial enhancement of inflammatory response, followed by its resolution }\end{array}$ \\
\hline van Buul [72] & $\begin{array}{l}\text { Platelet count: } 845.3 \times 10^{6} / \mathrm{ml} \\
\text { Activation: } \mathrm{CaCl}_{2} \\
\text { Leukocytes: present }\end{array}$ & $\begin{array}{l}\text { Normalization of collagen II, aggrecan, ADAMTS4, MMP13 and PTGS2 } \\
\text { expression altered by IL-1ß } \\
\text { No influence on GAG content } \\
\text { Dose-dependent down-regulation of IL-1ß induced NF-kB activation }\end{array}$ \\
\hline Wu [75] & $\begin{array}{l}\text { Platelet count: - } \\
\text { Activation: Thrombin } \\
\text { Leukocytes: - }\end{array}$ & $\begin{array}{l}\text { Dose-dependent increase in chondrocyte proliferation in collagen 3D arthritic } \\
\text { model } \\
\text { Restoration of collagen II, PG, integrin } \alpha 1 \beta 1 \text { and CD } 44 \text { expression inhibited } \\
\text { by IL-1ß and TNF } \alpha \\
\text { Inhibition of IL- } 1 \beta, \mathrm{COX}-2 \text {, and MMP-2 genes expression }\end{array}$ \\
\hline Bendinelli [5] & $\begin{array}{l}\text { Platelet count: } 1,850 \pm 320 \times 10^{6} / \mathrm{ml} \\
\text { Activation: Thrombin }+\mathrm{CaCl}_{2} \\
\text { Leukocytes: present }\end{array}$ & $\begin{array}{l}\text { Antiinflammatory effect: inhibition of NF-kB transactivation activity through } \\
\text { HGF, IL4, and TNF } \alpha \text {, and inhibition of monocyte-like cells chemotaxis }\end{array}$ \\
\hline Spreafico [69] & $\begin{array}{l}\text { Platelet count: } 1,460 \times 10^{3} / \mu 1 \\
\text { Activation: Ca-gluconate } \\
\text { Leukocytes: - }\end{array}$ & $\begin{array}{l}5 \% \text { PRPr optimal concentration for chondrocytes proliferation increase } \\
\text { Higher PRP concentration does not further induce cell proliferation } \\
\text { Increase in collagen II and PG production at day } 2 \text { that decreases over time }\end{array}$ \\
\hline Drengk [11] & $\begin{array}{l}\text { Platelet count: - } \\
\text { Activation: } \mathrm{CaCl}_{2} \\
\text { No leukocytes }\end{array}$ & $\begin{array}{l}\text { Increase in chondrocyte proliferation, but inhibition of chondrogenic markers } \\
\text { expression }\end{array}$ \\
\hline Pettersson [60] & $\begin{array}{l}\text { Platelet count: - } \\
\text { Activation: - } \\
\text { Leukocytes: - }\end{array}$ & $\begin{array}{l}\text { No beneficial effect on chondrocyte seeded macroporous gelatin microcarriers } \\
\text { in terms of histologic characteristics and proteoglycan deposition up to } \\
16 \text { weeks }\end{array}$ \\
\hline Saito [61] & $\begin{array}{l}\text { Platelet count: } 1,081 \pm 150 \times 10^{4} / \mu 1 \\
\text { Activation: Thrombin }+\mathrm{CaCl}_{2} \\
\text { No leukocytes }\end{array}$ & Increase in GAG content \\
\hline Akeda [1] & $\begin{array}{l}\text { Platelet count: } 1,399 \pm 174 \times 10^{3} / \mathrm{ml} \\
\text { Activation: Thrombin }+\mathrm{CaCl}_{2} \\
\text { Leukocytes: - }\end{array}$ & $\begin{array}{l}\text { Stable cell phenotype } \\
\text { Increase in cell proliferation and amount of collagen II and PG synthesis, more } \\
\text { than PPP or FBS }\end{array}$ \\
\hline
\end{tabular}


Table 1 continued

\begin{tabular}{|c|c|c|}
\hline Publications & PRP characteristics & PRP effects \\
\hline Gaissmaier [19] & $\begin{array}{l}\text { Platelet count: - } \\
\text { Activation: Thrombin }+\mathrm{Ca}- \\
\text { gluconate } \\
\text { No leukocytes }\end{array}$ & $\begin{array}{l}\text { Increase in chondrocyte proliferation in dose-dependent manner (stable above } \\
10 \% \text { ) } \\
\text { with inhibition of chondrogenic markers expression in monolayer culture as } \\
\text { well as in 3D culture model }\end{array}$ \\
\hline Kaps [33] & $\begin{array}{l}\text { Platelet count: - } \\
\text { Activation: freezing and thawing } \\
\text { No leukocytes }\end{array}$ & $\begin{array}{l}\text { Growth promotion activity comparable or superior to mitogenic stimulation } \\
\text { by FCS on articular and nasal septal chondrocytes } \\
\text { Reduction in ECM formation in chondrocyte/agarose construct }\end{array}$ \\
\hline Yang [76] & $\begin{array}{l}\text { Platelet count: - } \\
\text { Activation: freezing and thawing } \\
\text { No leukocytes }\end{array}$ & $\begin{array}{l}\text { Increase in chondrocytes proliferation with } 1 \% \text { PS } \\
\text { Chondrocytes mass formation with } 10 \% \text { PS } \\
\text { Increase in GAG but inhibition of collagen II expression }\end{array}$ \\
\hline \multicolumn{3}{|l|}{ MSCs + chondrocytes } \\
\hline Mifune [48] & $\begin{array}{l}\text { Platelet count: } 230 \times 10^{4} / \mathrm{ml} \\
\text { Activation: Thrombin }+\mathrm{CaCl}_{2} \\
\text { Leukocytes: - }\end{array}$ & $\begin{array}{l}\text { Promotion of proliferation, adhesion, and migration of MDSCs } \\
\text { Increase in cell apoptosis and number of collagen II producing cells }\end{array}$ \\
\hline Moreira Teixeira [53] & $\begin{array}{l}\text { Platelet count: - } \\
\text { Activation: freezing and thawing } \\
\text { No leukocytes }\end{array}$ & $\begin{array}{l}\text { High collagen II gene expression and synthesis } \\
\text { Chemo-attractant properties in hydrogel } \\
\text { Combination with hydrogel allowed retention of PRP at the defect site }\end{array}$ \\
\hline \multicolumn{3}{|l|}{ Meniscal cells } \\
\hline Gonzales [23] & $\begin{array}{l}\text { Platelet count: } 140 \pm 20 \times 10^{9} / 1 \\
\text { Activation: - } \\
\text { Leukocytes: - }\end{array}$ & $\begin{array}{l}\text { Same positive effect as FBS for meniscal cell culture } \\
\text { Dose-dependent effect: } 10 \text { and } 20 \% \text { PRP increased proliferation rate and } \\
\text { influenced more type I collagen and aggrecan expression at day } 7 \text { with } \\
\text { respect to } 5 \% \text { PRP }\end{array}$ \\
\hline Ishida [30] & $\begin{array}{l}\text { Platelet count: } 104.5 \times 10^{4} / \mu 1 \\
\text { Activation: - } \\
\text { Leukocytes: - }\end{array}$ & $\begin{array}{l}\text { Increase in meniscal cells proliferation in a dose-dependent manner } \\
\text { No effect on collagen I but modulation of GAG synthesis, } \\
\text { high biglycan and decorin expression, aggrecan downregulation }\end{array}$ \\
\hline \multicolumn{3}{|l|}{ Synoviocytes } \\
\hline Browning [6] & $\begin{array}{l}\text { Platelet count: - } \\
\text { Activation: - } \\
\text { Leukocytes: present }\end{array}$ & $\begin{array}{l}\text { Increase in MMP1, } 3 \text {, IL- } 6 \text { and decrease in PDGF- } \beta \beta \text {, MIP- } 1 \beta \text {, RANTES in } \\
\text { OA synoviocytes } \\
\text { Higher pro-inflammatory response than PPP treatment }\end{array}$ \\
\hline Anitua [2] & $\begin{array}{l}\text { Platelet count: } 494 \times 10^{6} / \mathrm{ml} \\
\text { Activation: } \mathrm{CaCl}_{2} \\
\text { No leukocytes }\end{array}$ & $\begin{array}{l}\text { Increase in HA secretion, further enhancement in the presence of IL-1B } \\
\text { Angiogenesis switched to a more balanced status } \\
\text { No effect on MMP1, 3, and VEGF amounts elicited by IL-1ß }\end{array}$ \\
\hline \multicolumn{3}{|l|}{ Mesenchymal stem cells } \\
\hline Hildner [28] & $\begin{array}{l}\text { Platelet count: - } \\
\text { Activation: - } \\
\text { Leukocytes: - }\end{array}$ & $\begin{array}{l}\text { Increase in proliferation } \\
\text { Increase in GAG and cartilage markers } \\
\text { Better redifferentiation potential than FCS expanded cells }\end{array}$ \\
\hline Kruger [42] & $\begin{array}{l}\text { Platelet count: } 0.6-1.3 \times 10^{10} / \mathrm{ml} \\
\text { Activation: freezing and thawing } \\
\text { Leukocytes: }<0.3 \times 10^{4} / \mathrm{ml}\end{array}$ & $\begin{array}{l}\text { Increase CSP migration with } 0.1-100 \% \text { PRP, especially with } 5 \% \text { PRP } \\
\text { Induction in chondrogenic markers' expression } \\
\text { Induced formation of cartilage matrix rich in PG and collagen II }\end{array}$ \\
\hline Moreira Teixeira [53] & $\begin{array}{l}\text { Platelet count: - } \\
\text { Activation: freezing and thawing } \\
\text { No leukocytes }\end{array}$ & $\begin{array}{l}\text { In hydrogel-PL increase in BMSCs proliferation rate, adhesion, and migration } \\
\text { No beneficial effect on collagen II mRNA expression in MSCs with } \\
\text { chondrogenic medium and PL, but higher expression in control medium and } \\
\text { PL }\end{array}$ \\
\hline Murphy [55] & $\begin{array}{l}\text { Platelet count: } 10^{6} / \mu 1 \\
\text { Activation: } \mathrm{CaCl}_{2} \\
\text { No leukocytes }\end{array}$ & $\begin{array}{l}\text { PRP is more mitogenic than FBS on MSCs derived from human and rat BM } \\
\text { and from rat compact bone } \\
\text { Higher increase in MSCs proliferation rate and migration with ucPRP with } \\
\text { respect to aPRP }\end{array}$ \\
\hline Mishra [52] & $\begin{array}{l}\text { Platelet count: } 10^{6} / \mathrm{ml} \\
\text { No activation } \\
\text { Leukocytes: present }\end{array}$ & $\begin{array}{l}\text { Induction of MSCs proliferation } \\
\text { Increase in chondrogenic markers' expression (SOX9, Aggrecan) }\end{array}$ \\
\hline
\end{tabular}


Table 1 continued

\begin{tabular}{|c|c|c|}
\hline Publications & PRP characteristics & PRP effects \\
\hline Drengk [11] & $\begin{array}{l}\text { Platelet count: - } \\
\text { Activation: } \mathrm{CaCl}_{2} \\
\text { No leukocytes }\end{array}$ & $\begin{array}{l}\text { Stimulation of BMSCs proliferation and weak chondrogenic differentiation in } \\
\text { a 3D environment }\end{array}$ \\
\hline Zaky [78] & $\begin{array}{l}\text { Platelet count: } 1-1.8 \times 10^{6} / \mu 1 \\
\text { Activation: freezing and thawing } \\
\text { No leukocytes }\end{array}$ & $\begin{array}{l}\text { Induction of proliferation (more than with FBS and FGF2) during the initial } \\
\text { culture passage } \\
\text { Induced MSCs chondrogenic differentiation in conditions without FBS }\end{array}$ \\
\hline Kakudo [32] & $\begin{array}{l}\text { Platelet count: } 132.26 \times 10^{4} / \mu \mathrm{l} \\
\text { Activation: Thrombin }+\mathrm{CaCl}_{2} \\
\text { Leukocytes: - }\end{array}$ & $\begin{array}{l}\text { Higher increase in ADMSCs proliferation with } 5 \% \text { PRP } \\
\text { Higher proliferation induction with activated PRP versus not activated PRP } \\
\text { Decrease in a dose-dependent manner with } 10 \text { and } 20 \% \text { PRP }\end{array}$ \\
\hline
\end{tabular}

time-dependent regulation and the dose-dependency effect. In particular, they tested different PRP concentrations (0.1, $1,5,10$, and $20 \%$ ) showing an increase in cellular viability in a dose-dependent manner. Yang et al. [76] reported that $1 \%$ of platelet supernatant (PS) is sufficient to stimulate chondrocyte proliferation, whereas $10 \%$ PS stimulated chondrocyte mass formation. Spreafico et al. [69] studied PRP releasate (PRPr) at 1, 5, and $10 \%$ and found that $5 \%$ was the optimal concentration to increase chondrocyte proliferation. Moreover, Gaissmaner et al. [19] provided evidence of cell proliferation increase with 1 or $10 \% \mathrm{PS}$, but no further stimulation occurred using concentrations above $10 \%$.

Together with chondrogenic phenotypic maintenance, other authors also documented an increase in matrix molecule production. Akeda et al. [1] documented that PRP treatment led to higher amounts of collagen II and PG synthesis than platelet poor plasma (PPP) or fetal bovine serum (FBS). Since cell-matrix interactions play an important role in maintaining cartilage homoeostasis, $\mathrm{Wu}$ et al. [75] designed a simple 3D chondrocyte model: in a collagen matrix, the authors mimicked an OA environment by IL-1ß and TNF $\alpha$ induction. Also in this model, PRP increased the membrane receptors integrin $\alpha 1 \beta 1$ and CD44 and favoured type II collagen and PG production. In another experimental model, Yin et al. [77] reported that PRP allowed the integration of an agarose construct with cartilage samples, showing a denser extracellular matrix (ECM) deposition in the integration area. Interestingly, Pereira et al. [59] found that the PRP stimulatory effect was limited over time: after an initial positive staining for collagen type II and PG, at 20 doublings the matrix/cells ratio decreased. Similarly, Spreafico et al. [69] documented an increase in PG release 2 days after PRPr treatment, followed by a decrease after 9 days, although at 20 days PG release remained still high.

Four papers focused on the role of PRP in OA chondrocytes as inflammation modulation. Pereira et al. [59] found that PL enhanced the initial inflammatory response and subsequently triggered its resolution through the regulation of nuclear factor kappa B (NF-kB) and cyclooxygenase-2 (COX-2), the principal actors of inflammatory cascade. Van Buul et al. [73] and Bendinelli et al. [5] confirmed the regulation of these key pathways by PRP in inflammatory conditions. Van Buul et al. [73] showed a dose-dependent down-regulation of IL-1ß-induced NF-kB activation, whereas Bendinelli et al. [5] showed that inhibition of NF-kB transactivation activity was mediated by HGF, a cytokine present in PRP $\alpha$-granules. Moreover, they suggested another anti-inflammatory action by inhibiting monocyte-like cell chemotaxis. Wu et al. [75] also investigated the anti-inflammatory potential of PRP in their 3D system: PRP counteracted the inflammatory cascade elicited by IL-1ß and TNF $\alpha$, showing an inhibition of IL-1ß, COX-2, and MMP-2 gene expression.

One article investigated the role of PRP as analgesic compound. Lee et al. [44] showed that the addition of PRP to a chondrocyte/hydrogel culture led to an immediate increase in mRNA levels of cannabinoid receptor CB1 and CB2 (receptors involved in analgesic and anti-inflammatory effects).

\section{Chondrocytes and MSCs co-culture}

In a system of OA chondrocytes and muscle-derived MSCs (MDSCs), Mifune et al. [48] observed that PRP promoted proliferation, adhesion, and migration of MDSCs. During chondrogenic pellet culture, PRP tended not only to increase the number of type II collagen-producing cells, but also to increase cell apoptosis, which, however, was not confirmed by the in vivo evaluation. Moreira Teixeira et al. [53] showed high expression and synthesis of collagen II co-culturing chondrocytes and expanded bone marrow MSCs (BMSCs) when PL/hydrogel was added. Moreover, they investigated the retention of PL/hydrogel construct in a cartilage fragment: the combination with hydrogel allowed the retention of PRP at the defect site, filling up irregularities at the cartilage surface. 
Table 2 In vivo preclinical studies

\begin{tabular}{|c|c|c|c|c|c|}
\hline Publication & $\begin{array}{l}\text { Animal } \\
\text { model }\end{array}$ & Lesion type & PRP characteristics & Protocol & PRP effects \\
\hline Mifune [48] & 36 rats & $\mathrm{OA}$ & $\begin{array}{l}\text { Platelet count: } 230 \times 10^{4} / \mathrm{ml} \\
\text { Activation: } \\
\text { Thrombin }+\mathrm{CaCl}_{2} \\
\text { Leukocytes: - }\end{array}$ & 1 injection $(30 \mu \mathrm{l})$ & $\begin{array}{l}\text { Promotion of collagen II } \\
\text { synthesis and suppression of } \\
\text { chondrocyte apoptosis only } \\
\text { when applied with MDSCs at } \\
4 \text { weeks } \\
\text { At } 12 \text { weeks, lost beneficial } \\
\text { effect }\end{array}$ \\
\hline Hapa [25] & 42 rats & Chondral lesion & $\begin{array}{l}\text { Platelet count: } 13.8 \times 10^{9} / 1 \\
\text { Activation: - } \\
\text { Leukocytes: - }\end{array}$ & $\begin{array}{l}1 \text { intra-op injection }(150 \mu \mathrm{l}) \\
1 \text { intra-articular injection } \\
(150 \mu \mathrm{l})\end{array}$ & $\begin{array}{l}\text { Better cartilage healing and } \\
\text { increase in type II collagen } \\
\text { expression at } 6 \text { weeks }\end{array}$ \\
\hline Guner [24] & 20 rats & $\mathrm{OA}$ & $\begin{array}{l}\text { Platelet count: - } \\
\text { Activation: } \\
\text { Thrombin }+\mathrm{CaCl}_{2} \\
\text { Leukocytes: - }\end{array}$ & 3-weekly injections $(50 \mu \mathrm{l})$ & $\begin{array}{l}\text { No significant effects regarding } \\
\text { cartilage healing at short term } \\
\text { ( } 2 \text { weeks after injection cycle) }\end{array}$ \\
\hline Serra [66] & 36 rabbits & $\begin{array}{l}\text { Osteochondral } \\
\text { lesion }\end{array}$ & $\begin{array}{l}\text { Platelet count: - } \\
\text { Activation: } \mathrm{CaCl}_{2} \\
\text { No leukocytes }\end{array}$ & $\begin{array}{l}7 \text { injections every } 2 \text { days } \\
(0.25 \mathrm{ml})\end{array}$ & $\begin{array}{l}\text { No macroscopic, microscopic, } \\
\text { and biomechanical additional } \\
\text { benefits from PRP injections up } \\
\text { to } 19 \text { weeks }\end{array}$ \\
\hline Kwon [43] & 21 rabbits & $\mathrm{OA}$ & $\begin{array}{l}\text { Platelet count: } \\
2664 \pm 970 \times 10^{3} / \mu 1 \\
\text { Activation: - } \\
\text { Leukocytes: - }\end{array}$ & 1 injection $(0.3 \mathrm{ml})$ & $\begin{array}{l}\text { Better cartilage regeneration in } \\
\text { all OA degrees at } 4 \text { weeks, in } \\
\text { particular in moderate knee OA }\end{array}$ \\
\hline Milano [49] & 30 sheep & Chondral lesion & $\begin{array}{l}\text { Platelet count: } \\
\quad 868 \pm 112 \times 10^{3} / \mathrm{ml} \\
\text { No activation } \\
\text { No leukocytes }\end{array}$ & 5-weekly injections $(3 \mathrm{ml})$ & $\begin{array}{l}\text { Improvement in macroscopic, } \\
\text { histologic, and biomechanical } \\
\text { cartilage repair after } \\
\text { microfractures, with more } \\
\text { durable results } \\
\text { No hyaline cartilage production } \\
\text { up to } 12 \text { months }\end{array}$ \\
\hline Milano [50] & 30 sheep & Chondral lesion & $\begin{array}{l}\text { Platelet count: } 2 \times \text { conc } \\
\text { No activation } \\
\text { No leukocytes }\end{array}$ & 5-weekly injections $(2-3 \mathrm{ml})$ & $\begin{array}{l}\text { Promotion of cartilage healing } \\
\text { until } 6 \text { months after treatment } \\
\text { (not at } 12 \text { months) } \\
\text { No hyaline cartilage production }\end{array}$ \\
\hline Lippross [45] & 15 pigs & AR & $\begin{array}{l}\text { Platelet count: } 1 \times 10^{6} / \mu \mathrm{l} \\
\text { Activation: - } \\
\text { Leukocytes: - }\end{array}$ & $\begin{array}{l}2 \text { injections every } 2 \text { weeks } \\
(5 \mathrm{ml})\end{array}$ & $\begin{array}{l}\text { Reduction in IL- } 6 \text { expression and } \\
\text { staining, and VEGF staining } \\
\text { Recovery of chondral protein } \\
\text { concentration levels } \\
\text { Reduction in IL-1ß and IGF-1 on } \\
\text { synoviocytes }\end{array}$ \\
\hline Milano [51] & 15 sheep & Chondral lesion & $\begin{array}{l}\text { Platelet count: } \\
1,415 \pm 164 \times 10^{3} / \mathrm{ml} \\
\text { Liquid PRP: no activation } \\
\text { PRP gel: } \mathrm{Ca}- \\
\text { gluconate }+ \text { fibrin glue } \\
\text { Leukocytes: - }\end{array}$ & 1 injection $(5 \mathrm{ml})$ & $\begin{array}{l}\text { Improvement in macroscopic, } \\
\text { histologic and biomechanical } \\
\text { scores, no hyaline cartilage } \\
\text { production } \\
\text { Better results with PRP gel at } \\
6 \text { months }\end{array}$ \\
\hline Saito [61] & 33 rabbits & $\mathrm{OA}$ & $\begin{array}{l}\text { Platelet count: } \\
1,081 \pm 150 \times 10^{4} / \mu 1 \\
\text { Activation: }- \\
\text { No leukocytes }\end{array}$ & $\begin{array}{l}2 \text { injections at } 4 \text { weeks and } \\
7 \text { weeks after OA induction } \\
(100 \mu \mathrm{l})\end{array}$ & $\begin{array}{l}\text { Suppression of OA progression } \\
\text { morphologically and } \\
\text { histologically by PRP } \\
\text { impregnated hydrogel } \\
\text { microspheres } \\
\text { (not significantly by the use of } \\
\text { PRP only) }\end{array}$ \\
\hline Carmona [7] & 4 horses & $\mathrm{OA}$ & $\begin{array}{l}\text { Platelet count: } \\
\qquad 250 \pm 71.8 \times 10^{6} / \mathrm{ml} \\
\text { Activation: } \mathrm{CaCl}_{2} \\
\text { Leukocytes: present }\end{array}$ & $\begin{array}{l}3 \text { injections at } 2 \text {-week } \\
\text { interval }(10-20 \mathrm{ml})\end{array}$ & $\begin{array}{l}\text { Improvement in both degree of } \\
\text { lameness and joint effusion, } \\
\text { with normal synovial fluid } \\
\text { parameters } \\
\text { Marked improvement at } \\
2 \text { months maintained up to } \\
8 \text { months }\end{array}$ \\
\hline
\end{tabular}


Synoviocytes

Anitua et al. [2] investigated the role of PRGF ('preparation rich in growth factors': a low-concentrate PRP without leukocytes) on OA synoviocytes with or without exposition to IL-1B, to mimic the overproduction of proinflammatory cytokines in the joint environment during OA progression. PRGF significantly enhanced HA secretion compared to PPP both with and without IL-1 $\beta$ and switched angiogenesis to a more balanced status, but did not modify the IL$1 \beta$-induced rise of matrix metallo-protease (MMP) 1, 3 and vascular endothelial growth factor (VEGF) produced by synovial cells. Indeed, Browning et al. [6] even showed an increase in MMP-1 and MMP-3 in OA synoviocytes incubated with PRP, thus suggesting that the application of PRP to synovial joints might be associated with deleterious effects due a pro-inflammatory response that might lead to an accelerated cartilage catabolism.

Meniscal cells

Ishida et al. [30] showed the usefulness of PRP not only because of its proliferation effect, but also its induction of GAG synthesis. PRP up-regulated the viability of meniscal cells in a dose-dependent manner, as well as the mRNA expression of biglycan and decorin. Gonzales et al. [23] investigated whether PRP might fully replace FBS for cultured tissue engineering constructs. The study results showed that PRP presents the same positive effect as FBS for meniscal cell culture and showed that dosage is an important aspect of the induced effect: 10 and $20 \%$ PRP increased proliferation rate and influenced more type I collagen and aggrecan expression at day 7 of culture with respect to $5 \%$ PRP.

\section{Stem cells}

Eight papers investigated the effect of PRP on MSCs of different origin: 1 on subchondral cortico-spongious bone (CSP) cells, 1 on commercial human MSCs, 4 on BMSCs, and 2 on adipose-derived MSCs (ADMSCs).

Kruger et al. [42] investigated the migration and chondrogenic differentiation of human subchondral progenitors. In particular, a chemotactic assay revealed that PRP significantly stimulated the migration of CSPs, together with their chondrogenic differentiation and production of PG and collagen type II. Zaky et al. [78] and Drengk et al. [11] confirmed an induced chondrogenic differentiation of BMSCs, which also presented a higher proliferation rate. Mishra et al. [52] documented the same behaviour on MSCs with a higher proliferation rate and a selective differentiation along the chondrogenic line: SOX9 and aggrecan (chondrogenic markers) were increased much more than RUNX2 (osteogenic marker). Conversely, Moreira Teixeira et al. [53] reported that PL, besides inducing a significant increase in BMSCs proliferation rate and migration, did not induce an increase in collagen type II.

Hildner et al. [28] focused on ADMSCs and showed strongly enhanced proliferation rates with retained chondrogenic differentiation potential and even a tendency toward increased chondrogenic differentiation of PLexpanded ADMSCs compared to FCS. Kakudo et al. [32] studied the proliferation of ADMSCs treated with PRP with or without activation and at different concentrations (1, 5, 10 , or $20 \%$ ). Results showed the importance of both PRP activation and correct dosage: in fact, the stronger promotion of proliferation was observed in PRP activated with calcium chloride and autologous thrombin and applied at $5 \%$, whereas at higher platelet concentrations the proliferation rate decreased in a dose-dependent manner.

Finally, Murphy et al. [55] tested two different types of PRP: one derived from human adult peripheral blood and one derived from human umbilical cord blood (ucPRP), showing the superiority of ucPRP with regard to MSCs proliferation and migration induction.

\section{In vivo preclinical studies}

Concerning in vivo preclinical studies dealing with PRP injective treatment, we found 11 papers: 3 on rat, 3 on rabbit, 3 on sheep, 1 on pig, and 1 on horse, which showed heterogeneous results for heterogeneous indications.

Five papers focused on OA treatment. Contrasting results have been reported in the small animal model. In fact, whereas Guner et al. [24] did not find any immediate ( 2 weeks after the injection cycle) benefit of PRP on cartilage tissue in rat joints previously damaged with intraarticular formalin injection, Mifune et al. [48] found in a rat OA model, induced by monosodium iodoacetate injection, that PRP had no marked effect by itself, but increased the cartilage repair effect of MDSCs, with a better histologic appearance, higher number of cells producing type II collagen, and lower levels of chondrocyte apoptosis at 4 weeks, although at 12 weeks its effects were lost. Kwon et al. [43] confirmed the benefit of PRP in a rabbit model of collagenase-induced OA: intra-articular injections influenced positively cartilage regeneration in all OA severity degrees, with a more evident effect in moderate OA. Saito et al. [61] used a rabbit OA model of anterior cruciate ligament resection for the treatment with gelatin hydrogel microspheres impregnated with PRP: injections markedly suppressed OA progression both morphologically and histologically (less significant results were obtained by the use of PRP only). Finally, Carmona 


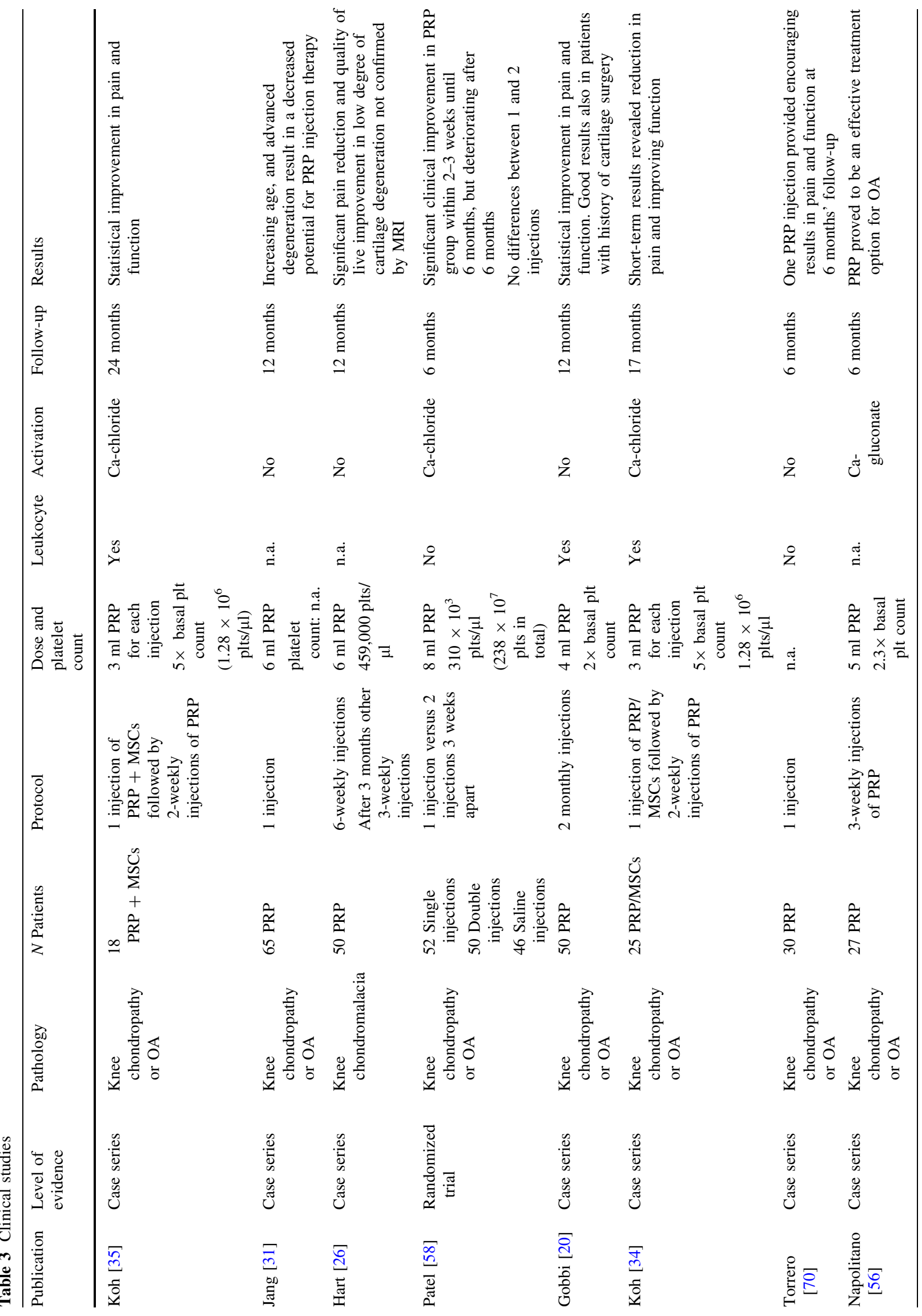




\begin{tabular}{|c|c|c|c|c|c|c|c|c|c|}
\hline$\frac{\mathscr{a}}{\vec{z}}$ & 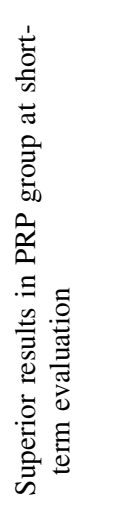 & 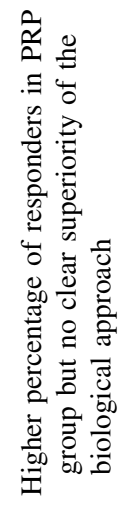 & 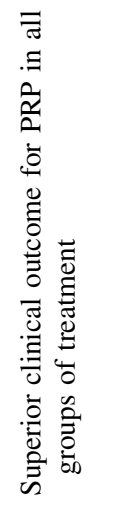 & 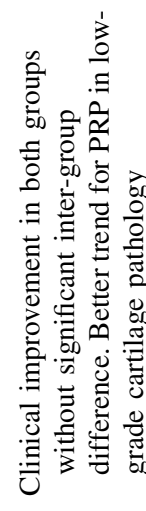 & 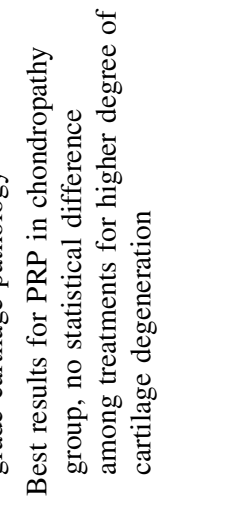 & 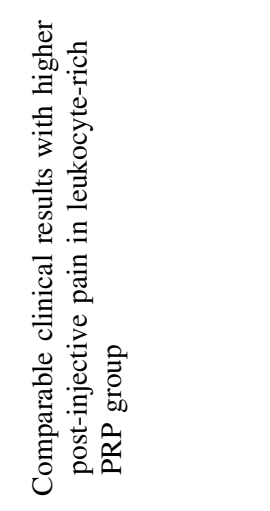 & 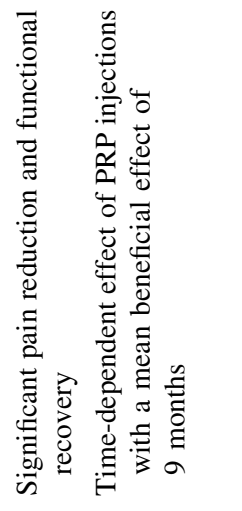 & 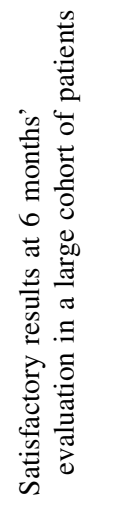 & 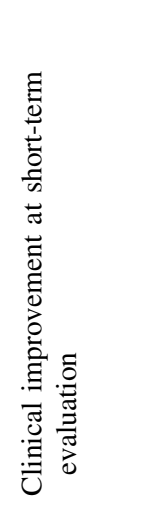 \\
\hline 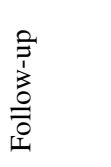 & $\begin{array}{l}\text { a } \\
\text { हूँ } \\
\text { है }\end{array}$ & $\begin{array}{l}0 \\
E \\
0 \\
\Xi \\
0\end{array}$ & 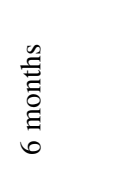 & $\begin{array}{l}\text { 号 } \\
\text { 音 } \\
\text { ב }\end{array}$ & 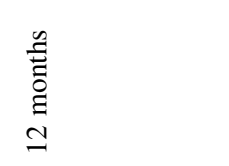 & 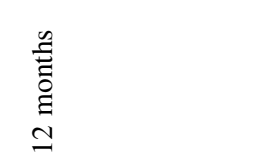 & 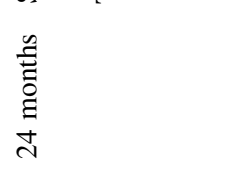 & $\begin{array}{l}\mathscr{E} \\
\bar{\Xi} \\
\Xi \\
\Xi\end{array}$ & $\begin{array}{l}\text { ص } \\
\bar{E} \\
\vdots \\
\Xi \\
0\end{array}$ \\
\hline : & z & 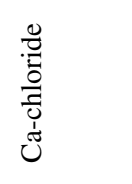 & z & $\begin{array}{l}\frac{0}{0} \\
\frac{0}{0} \\
\frac{\pi}{0} \\
\frac{1}{0} \\
0\end{array}$ & $\begin{array}{l}\frac{0}{D} \\
\frac{0}{0} \\
0 \\
0 \\
0 \\
0 \\
0\end{array}$ & 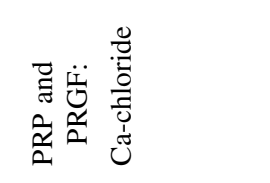 & $\begin{array}{l}\frac{0}{0} \\
\frac{0}{0} \\
\frac{0}{0} \\
\frac{1}{0} \\
0 \\
0\end{array}$ & $\begin{array}{l}\frac{0}{0} \\
\frac{0}{0} \\
\frac{\pi}{0} \\
\frac{1}{0} \\
\tilde{d}\end{array}$ & 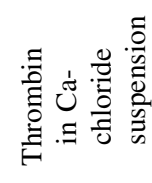 \\
\hline & $\stackrel{0}{\infty}$ & $\stackrel{\circ}{z}$ & $\stackrel{\circ}{z}$ & $\stackrel{\mathscr{D}}{\nu}$ & $\overbrace{\nu}^{\infty}$ & 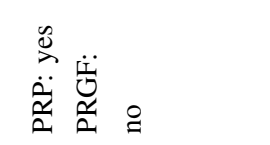 & $\overbrace{\nu}^{\infty}$ & z & $\stackrel{\text { İ }}{=}$ \\
\hline 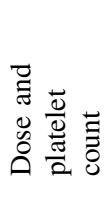 & 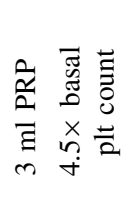 & 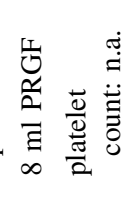 & 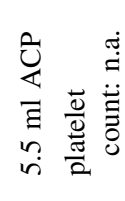 & 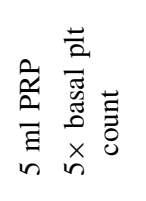 & 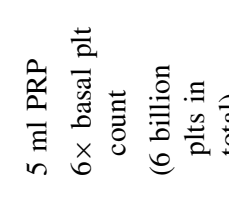 & 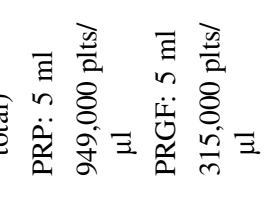 & 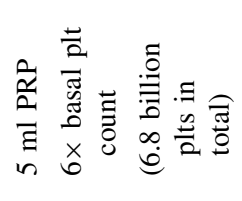 & $\stackrel{\stackrel{\nexists}{\sharp}}{\sharp}$ & 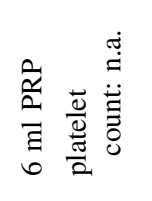 \\
\hline $\begin{array}{l}\overline{0} \\
0 \\
0 \\
0 \\
0\end{array}$ & 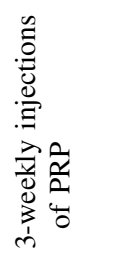 & 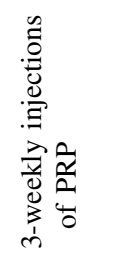 & 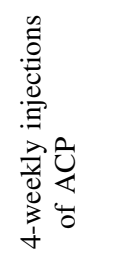 & 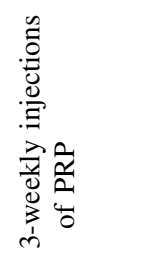 & 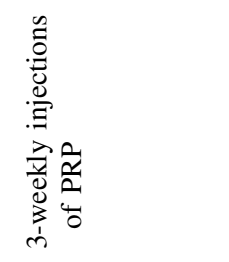 & 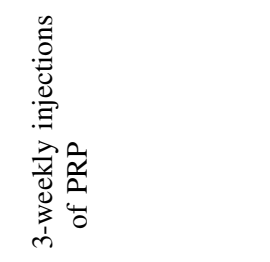 & 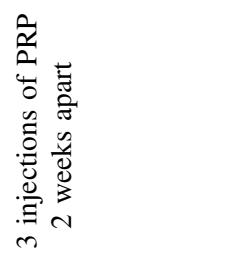 & 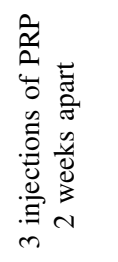 & 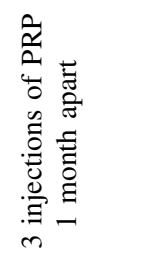 \\
\hline 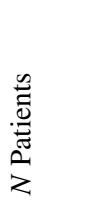 & 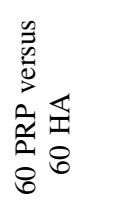 & 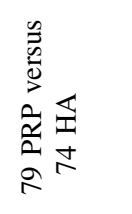 & 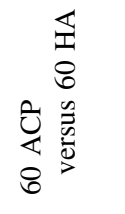 & 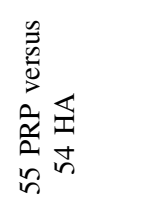 & 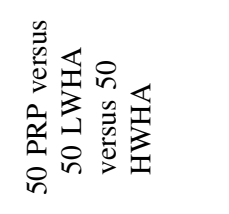 & 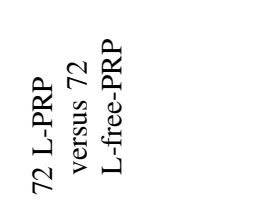 & $\begin{array}{l}\frac{2}{2} \\
\frac{2}{2}\end{array}$ & $\begin{array}{l}\vec{a} \\
\overrightarrow{0} \\
\vec{i}\end{array}$ & $\begin{array}{l}\vec{\alpha} \\
\text { a } \\
\pm\end{array}$ \\
\hline $\begin{array}{l}\text { के } \\
\text { ० } \\
0 \\
\text { है } \\
0\end{array}$ & 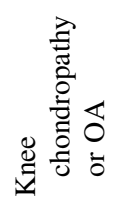 & 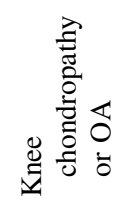 & 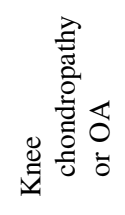 & 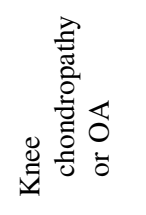 & 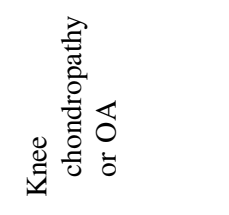 & 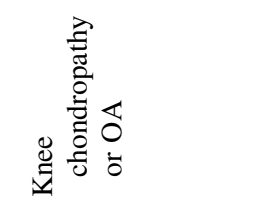 & 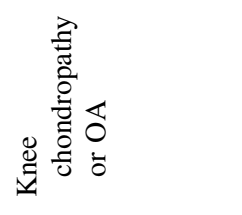 & 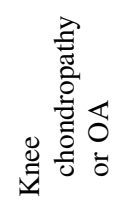 & 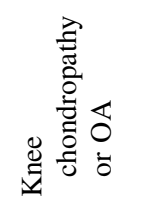 \\
\hline 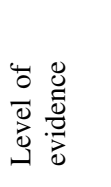 & 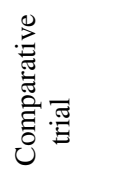 & 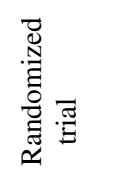 & 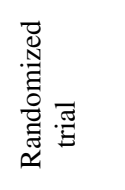 & 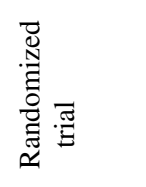 & 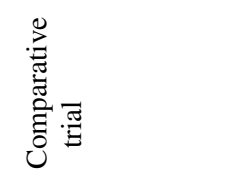 & 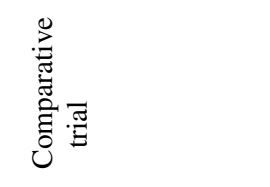 & 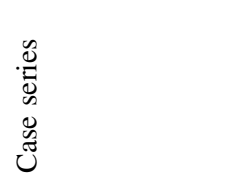 & $\begin{array}{l}\mathscr{0} \\
\stackrel{\tilde{D}}{0} \\
0 \\
0 \\
\tilde{z}\end{array}$ & $\begin{array}{l}\mathscr{0} \\
: \overline{0} \\
0 \\
0 \\
\tilde{J} \\
\tilde{J}\end{array}$ \\
\hline 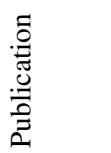 & 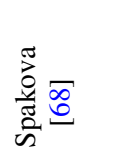 & 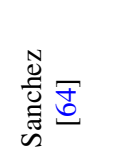 & $\frac{\infty}{\tilde{N}}$ & 总 & $\begin{array}{l}\bar{\Xi} \\
\bar{\Xi} \\
\check{\varepsilon}\end{array}$ & 鄫巨 & 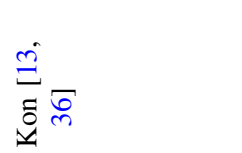 & 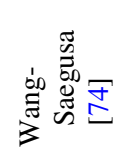 & 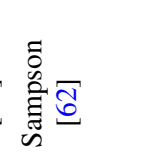 \\
\hline
\end{tabular}




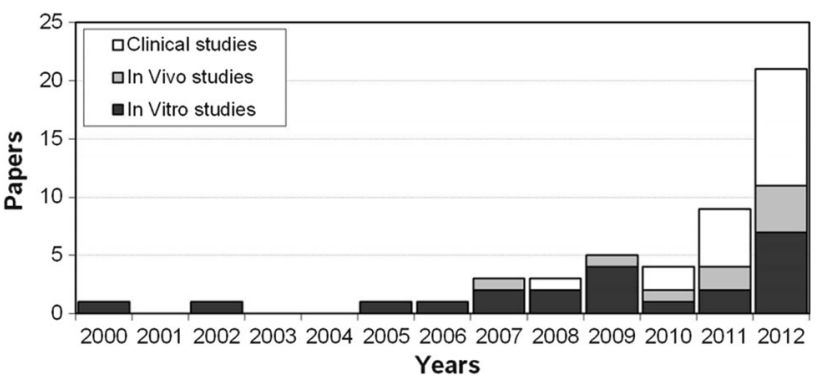

Fig. 1 The analysis of per year publication shows the interest in PRP application for the treatment of cartilage lesions or joint degeneration with an increasing number of published studies over time

et al. [7] used a large animal model to analyze the effect of PRP injections: in a study on 4 horses with OA, 3 injections of PRP led to a significant improvement in both the degree of lameness and joint effusion. The most marked improvement was observed 2 months after treatment and persisted for 8 months with no adverse events.

Five studies focused on the injective treatment of chondral or osteochondral lesions. Also in this case, results were controversial. Serra et al. [66] performed 7 PRP injections every other day in rabbit joints where a fullthickness osteochondral lesion was previously made surgically on the medial femoral condyle. A fibrous-cartilaginous tissue was found with no benefit from PRP. Hapa et al. [25] evaluated PRP as augmentation in rat cartilage lesions after microfractures: at week 6 , the microfracture group score was worse than that of the PRP + microfracture group, which had an increased degree of type II collagen staining. Milano et al. [51] used one PRP injection as augmentation procedure of microfracture in a sheep model. Although no hyaline cartilage was obtained, PRP offered better macroscopic, histologic, and biomechanical results. The PRP administration modality proved to be important for the final outcome, with better results when PRP was surgically applied as a gel over the treated lesion. However, this required a more invasive approach. Thus, in a further evaluation in sheep, Milano et al. $[49,50]$ focused on the injective approach: 5-weekly injections of PRP promoted a better spontaneous repair and also a better and more durable reparative response when applied after microfractures with respect to isolated microfractures, albeit without producing hyaline cartilage.

Finally, only 1 paper focused on rheumatoid arthritis (RA). Lippross et al. [45] reproduced RA in pigs: the animals were systemically immunized by bovine serum albumin (BSA) injections, and arthritis was induced by intra-articular BSA injection. The injection of PRP attenuated the arthritic changes on synovium and cartilage by modulating the activity of inflammation mediators. In particular, IL-6 and VEGF staining was reduced, but concerning gene expression, only IL-6 levels were 
significantly lower after PRP application. Focusing on protein quantification, all chondral protein concentrations returned to healthy tissue levels, and in synovial samples, besides the low levels of IL-6 and VEGF, the authors showed a reduction in IGF-1 and IL-1 in PRP groups, whereas TNFa was not altered.

\section{Clinical studies}

Intra-articular clinical application of PRP has been tested in several clinical studies to date. The present search identified 22 clinical trials that met the inclusion criteria: among these, 13 were case series, 4 were comparative studies, and 5 were randomized trials. The majority of the available papers deal with application in the knee.

The first comparative evaluation was performed by Sanchez et al. [63] in 2008 who published a retrospective observational study on 60 patients, 30 treated with 3 knee intra-articular injections of PRGF and 30 with 3 injections of hyaluronic acid (HA). Results at 5 weeks were encouraging, with PRGF showing better efficacy in pain control. Afterwards, Kon et al. [41] in 2011 performed a prospective comparative study testing PRP against low molecular weight HA (LW-HA) and high molecular weight HA (HW-HA) in 3 homogeneous groups of 50 patients each. The results showed a better performance for the PRP group at 6 months of follow-up. In particular, PRP produced superior results in the 'chondropathy' group. Conversely, in the early OA group the difference with HA was not significant and in the severe OA group no difference in clinical outcome was observed. Another interesting finding was that patients aged up to 50 years old had a greater chance to benefit from the PRP approach. The same authors were the only ones to compare two different PRP preparations: high-concentrate leukocyte-rich PRP versus lowconcentrate leukocyte-free PRP. One hundred forty-four patients were treated and evaluated up to 12 months and comparable positive results were obtained with both treatments, with the only difference being that the PRPleukocyte group suffered from more swelling and pain reaction immediately after the injections [37]. Spakova et al. [68] also compared the efficacy of PRP versus visco supplementation in 120 patients. An increase in the clinical scores was reported in both groups at 6 months, but statistically superior results were found in the PRP group.

Recently, five randomized controlled trials have been published. Sanchez et al. [64] investigated the efficacy of single-spinning leukocyte-free PRP compared to HA in 153 patients evaluated up 6 months of follow-up. The only aspect where a clear superiority of PRP was found was the percentage of responders (patients with at least $50 \%$ of pain reduction), which was significantly higher in the PRP group. Besides this finding, the study did not show that PRP in moderate/severe OA was more effective than HA. Similar considerations were made by Filardo et al. [14], according to the preliminary results (109 patients) of their randomized double-blind trial comparing PRP and HA: no statistical inter-group difference was reported and just a tendency toward better results for the PRP group at 6 and 12 months of follow-up was found in patients affected by low-grade cartilage degeneration (Kellgren Lawrence up to 2). Conversely, Cerza et al. [8] treated 120 patients by either autologous conditioned plasma (ACP, a low-concentrate PRP without leukocytes) or HA. Surprisingly, the ACP group showed a significantly better performance than $\mathrm{HA}$ in all groups of treatment, including patients affected by grade 3 knee OA. Furthermore, the clinical gap between treatments increased over time in favour of ACP. Finally, a recent randomized trial by Patel et al. [58] was the first to test PRP versus saline. Seventy-eight patients affected by Kellgren grade I-III OA were included and treated bilaterally with one injection of PRP, two injection of PRP (3 weeks apart) or one injection of saline. Despite the low number of patients included [12], a significant difference was observed between PRP and saline solution in terms of clinical outcome. Interestingly, no difference was reported among patients who received one or two PRP injections.

Only one paper investigated the efficacy of PRP versus HA in osteochondral talar lesions on 30 patients [47]. In the short-term 28-week evaluation a superior clinical performance was found in the PRP group.

\section{Discussion}

This systematic review confirmed the increasing interest in PRP as an injective treatment for cartilage degeneration and OA, with an increasing number of published studies over time.

PRP is a fashionable treatment, offering the possibility to deliver a high concentration of autologous growth factors and bioactive molecules in physiologic proportions, with low costs and in a minimally invasive way. This explains the wide application of this blood derivative to several tissues and heterogeneous pathologies in different fields of medicine [38]. The rationale for using platelets for the treatment of different tissues is that they constitute a reservoir of growth factors that are critical to regulate the tissue healing process, which is quite similar in all kinds of tissues. However, whereas the rationale for PRP use in other tissues is clear, since platelets represent the first response to a tissue damage where they participate in stopping the vessel bleeding and trigger the healing cascade [9], less intuitive is the rationale for PRP use in cartilage, which is a physiologically vessel-free tissue. Moreover, whereas some 
molecules such as TGF- $\beta$ might justify its use in cartilage, PRP also contains other molecules such as VEGF that do not take part or might even jeopardize cartilage homeostasis and regeneration $[48,72]$. Thus, it is mandatory to investigate whether the overall effect of PRP is also beneficial for the peculiar requirements of cartilage tissue before an indiscriminate human application.

The systematic analysis of in vitro studies published up to now shows an overall positive effect of PRP on cartilage tissue. Besides some controversial results, most of the findings supported the role of PRP in increasing chondrocyte proliferation, without affecting chondrogenic phenotype and with an increase in the production of matrix molecules. These properties of PRP have provided positive results also in the animal model: preclinical studies confirmed the usefulness of PRP treatment in different pathology models, with good results in cartilage regeneration after acute focal lesions, as well as in the more complex environment of joint osteoarthritic degeneration, and even in the challenging RA setting.

Clinical studies on PRP injective treatment for joint degeneration also showed overall good results. Nonetheless, both the rapid clinical benefit and the limited effect over time are in contrast with the timing required by a hypothetically induced cartilage regeneration process. Despite the wide majority of studies focusing on cartilage tissue, it is actually likely that the clinical benefit reported after PRP injection is attributable to other action mechanisms.

An intra-articular injection does not just target cartilage, instead PRP might influence the entire joint environment, and some in vitro studies confirm the effects of PRP on other cell sources. Synoviocytes are affected by platelet releasate, as well as meniscal cells and also MSCs that seem to be induced by PRP and act synergically toward tissue healing. The chemo-attractant activity of PRP may contribute to the recruitment of other cells that might migrate into the damaged tissues, thus triggering the healing response [42, 53]. PRP has several potential effects by enhancing the cell signalling cascade in all joint tissues and inducing positive changes in the whole joint environment through a milieu of actions. Among these, tissue regeneration is actually not the only and maybe not the most important PRP mechanism of action, and increasing evidence supports the complex role of PRP in modulating inflammation. PRP showed both pro- and anti-inflammatory activities: an initial pro-inflammatory action [59] was reported, with synoviocyte stimulation for MMP and cytokine release [2], followed by a limitation of the inflammatory response by decreasing inflammatory molecules and preventing chemotaxis of monocytes-like cells [44, 75].

An overall down-modulation of the joint inflammation can explain the well-documented pain reduction, which is the most prominent and disabling symptom of cartilage lesions and knee OA. However, some findings suggest another intriguing aspect of PRP action mechanism, with a direct analgesic effect: Lee et al. [44] showed the role of PRP in the augmentation of cannabinoid receptors CB1 and CB2, which might be involved in the analgesic effects. Further studies need to focus on understanding and possibly optimizing the analgesic and anti-inflammatory effects of PRP.

PRP might not lead to hyaline cartilage regeneration and might not change the clinical history with significant disease-modifying properties, but it still might offer a clinical benefit with symptoms and function improvement and possibly a slowdown of the degenerative processes.

The central feature in OA cartilage degeneration is the so-called apoptosis (programmed cell death); thus, chondrocytes apoptosis is a potential therapeutic target for OA interventions. The exact mechanism behind the PRP regulation of the apoptotic pathway is unclear, but it is likely that PRP might have an overall effect in slowing down the apoptosis cascade. Among the hypothesized mechanisms, recent findings identified IGF-1 protein as a possible effector of apoptosis inhibition: Yin et al. [77] found that IGF-1 may down-regulate the expression of programmed cell death 5 (PDCD5), thus inhibiting the apoptosis of osteoarthritic chondrocytes. Interestingly, Mifune et al. [48] observed an increased cell apoptosis in the in vitro setting, which, however, was not confirmed by the subsequent in vivo experiment, where lower levels of apoptosis were detected. Thus, the authors suggested that it was the complex interaction of PRP with the different joint structures (synovium, fat pad, bone marrow,...), which might positively influence chondrocytes apoptosis.

The controversial findings reported underline the limits of preclinical studies, which do not exactly represent the peculiar human pathophysiology. Nonetheless, although such experimental settings do not replace the fundamental role of robust clinical trials, in vitro studies can suggest mechanisms of action and directions for improvement and might explain some controversial findings in the reports of PRP application in humans. As for other tissues [71], in vitro studies have shown the importance of the dosage of the potent platelet-derived growth factors, with different platelet concentrations leading to different results. Activation might also play an important role, as well as the appropriate cell population which is also a key aspect for obtaining optimal results [38]. With regard to this, leukocytes are a controversial PRP component, since some authors attribute better results to leukocyte depletion, because of the supposed deleterious effects of proteases and reactive oxygen species released from white cells, whereas other authors consider them as a source of cytokines and enzymes that may also be important for the prevention of infections [17]. Several other variables have to be considered, such as the preparation methods and the 
consequent presence of other cells, storage modalities, application protocols, and many other aspects that might not be of secondary importance for determining PRP properties and clinical efficacy [38]. The number of names and acronyms encountered searching for studies on this biological treatment approach, such as PRP, PRGF, ACP, PL, clearly represents the complexity of this field and explains the difficulties in literature analysis, study comparison, and understanding some contradictory results.

With the limits of a complex field still in its infancy, few studies and some controversial results, this systematic review still showed some important aspects. The first one is that the increasing interest in this topic is being translated into research with a growing number of papers published over time, which show promise in shedding some more light on PRP use in the near future. The second one is that, besides the limits and sometimes controversial findings of in vitro and animal studies, the preclinical literature documented an overall support toward PRP application for the injective treatment of cartilage lesions and OA. Moreover, some conclusions can be drawn also with regard to human application, which can be of clinical usefulness. The first one is the safety of PRP injections, with no major adverse events reported in the literature and only some reports of self-limiting immediate pain and swelling reaction $[17,36$, 41]. The second one is that all studies seem to agree on an overall clinical benefit of PRP. Better results with respect to saline have been shown, and some studies suggest a slight superiority of PRP with respect to visco supplementation [8, 14, 58, 64]. However, not all patient categories present the same results that are more significant in younger patients affected by not too advanced degeneration, and the clinical benefit is limited over time and can roughly be estimated at less than 1 year [13]. This might suggest that this treatment could be applied in cycles to ensure longer lasting results and postpone more invasive procedures. Finally, another aspect emerges from the literature analysis: whereas among the available techniques none clearly seemed to offer superior clinical results [17], it appears clear that there is room for a better targeting of this PRP application. Several aspects still need to be studied to understand the mechanism of action of PRP and give better treatment indications and possibly to optimize the procedure and improve the potential of this biological minimally invasive approach for the treatment of cartilage degeneration and OA.

\section{Conclusions}

One of the emerging fields of PRP treatment is its injective application for cartilage degeneration and OA, as shown by an increasing number of papers published on this topic over time. Preclinical evidence supports the use of PRP injections that might promote a favourable environment for joint tissues healing, targeting not only cartilage but also synovial and meniscal tissues. A few high-quality trials have been published, which showed the clinical usefulness of PRP but only with an improvement limited over time and mainly in younger patients not affected by advanced degeneration. Many biological variables might influence the clinical outcome and have to be studied to optimize PRP injective treatment in case of cartilage degeneration and $\mathrm{OA}$.

Acknowledgments E. Pignotti, K. Smith: Task Force, Rizzoli Orthopaedic Institute, Bologna, Italy. This work was supported by the following grant: Regione Emilia-Romagna-Programma di ricerca Regione-Università 2010-2012.

Open Access This article is distributed under the terms of the Creative Commons Attribution License which permits any use, distribution, and reproduction in any medium, provided the original author(s) and the source are credited.

\section{References}

1. Akeda K, An HS, Okuma M, Attawia M, Miyamoto K, Thonar EJ, Lenz ME, Sah RL, Masuda K (2006) Platelet-rich plasma stimulates porcine articular chondrocyte proliferation and matrix biosynthesis. Osteoarthritis Cartil 14(12):1272-1280

2. Anitua E, Sánchez M, Nurden AT, Zalduendo MM, de la Fuente M, Azofra J, Andía I (2007) Platelet-released growth factors enhance the secretion of hyaluronic acid and induce hepatocyte growth factor production by synovial fibroblasts from arthritic patients. Rheumatology (Oxford) 46(12):1769-1772

3. Anitua E, Sánchez M, Orive G (2010) Potential of endogenous regenerative technology for in situ regenerative medicine. Adv Drug Deliv Rev 15;62(7-8):741-752

4. Battaglia M, Guaraldi F, Vannini F, Buscio T, Buda R, Galletti S, Giannini S (2011) Platelet-rich plasma (PRP) intra-articular ultrasound-guided injections as a possible treatment for hip osteoarthritis: a pilot study. Clin Exp Rheumatol 29(4):754

5. Bendinelli P, Matteucci E, Dogliotti G, Corsi MM, Banfi G, Maroni P, Desiderio MA (2010) Molecular basis of anti-inflammatory action of platelet-rich plasma on human chondrocytes: mechanisms of NF- $\mathrm{BB}$ inhibition via HGF. J Cell Physiol 225(3):757-766

6. Browning SR, Weiser AM, Woolf N, Golish SR, SanGiovanni TP, Scuderi GJ, Carballo C, Hanna LS (2012) Platelet-rich plasma increases matrix metalloproteinases in cultures of human synovial fibroblasts. J Bone Joint Surg Am 94(23):e1721-e1727

7. Carmona JU, Arguelles D, Climent F, Prades M (2007) Autologous platelet concentrates as a treatment of horses with osteoarthritis: a preliminary pilot clinical study. J Equin Vet Sci 27;4:167-170

8. Cerza F, Carnì S, Carcangiu A, Di Vavo I, Schiavilla V, Pecora A, De Biasi G, Ciuffreda M (2012) Comparison between hyaluronic acid and platelet-rich plasma, intra-articular infiltration in the treatment of gonarthrosis. Am J Sports Med. doi:10.1177/ 0363546512461902

9. Cole BJ, Seroyer ST, Filardo G, Bajaj S, Fortier LA (2010) Platelet-rich plasma: where are we now and where are we going? Sports Health 2(3):203-210 
10. Della Villa S, Kon E, Filardo G, Ricci M, Vincentelli F, Delcogliano M, Marcacci M (2010) Does intensive rehabilitation permit early return to sport without compromising the clinical outcome after arthroscopic autologous chondrocyte implantation in highly competitive athletes? Am J Sports Med 38(1):68-77

11. Drengk A, Zapf A, Stürmer EK, Stürmer KM, Frosch KH (2009) Influence of platelet-rich plasma on chondrogenic differentiation and proliferation of chondrocytes and mesenchymal stem cells. Cells Tissues Organs 189(5):317-326

12. Filardo G, Di Matteo B, Kon E (2013) Treatment with plateletrich plasma is more effective than placebo for knee osteoarthritis: a prospective, double-blind, randomized trial. Letter to editor. Am J Sports Med 41(9):NP42-NP44

13. Filardo G, Kon E, Buda R, Timoncini A, Di Martino A, Cenacchi A, Fornasari PM, Giannini S, Marcacci M (2011) Platelet-rich plasma intra-articular knee injections for the treatment of degenerative cartilage lesions and osteoarthritis. Knee Surg Sports Traumatol Arthrosc 19(4):528-535

14. Filardo G, Kon E, Di Martino A, Di Matteo B, Merli ML, Cenacchi A, Fornasari PM, Marcacci M (2012) Platelet-rich plasma vs hyaluronic acid to treat knee degenerative pathology: study design and preliminary results of a randomized controlled trial. BMC Musculoskelet Disord 23;13(1):229

15. Filardo G, Kon E, Di Martino A, Iacono F, Marcacci M (2011) Arthroscopic second-generation autologous chondrocyte implantation: a prospective 7-year follow-up study. Am J Sports Med 39(10):2153-2160

16. Filardo G, Kon E, Di Martino A, Patella S, Altadonna G, Balboni F, Bragonzoni L, Visani A, Marcacci M (2012) Second-generation arthroscopic autologous chondrocyte implantation for the treatment of degenerative cartilage lesions. Knee Surg Sports Traumatol Arthrosc 20(9):1704-1713

17. Filardo G, Kon E, Pereira Ruiz MT, Vaccaro F, Guitaldi R, Di Martino A, Cenacchi A, Fornasari PM, Marcacci M (2012) Platelet-rich plasma intra-articular injections for cartilage degeneration and osteoarthritis: single- versus double-spinning approach. Knee Surg Sports Traumatol Arthrosc 20(10): 20-2091

18. Filardo G, Vannini F, Marcacci M, Andriolo L, Ferruzzi A, Giannini S, Kon E (2013) Matrix-assisted autologous chondrocyte transplantation for cartilage regeneration in osteoarthritic knees: results and failures at midterm follow-up. Am J Sports Med 41(1):95-100

19. Gaissmaier C, Fritz J, Krackhardt T, Flesch I, Aicher WK, Ashammakhi N (2005) Effect of human platelet supernatant on proliferation and matrix synthesis of human articular chondrocytes in monolayer and three-dimensional alginate cultures. Biomaterials 26(14):1953-1960

20. Gobbi A, Karnatzikos G, Mahajan V, Malchira S (2012) Plateletrich plasma treatment in symptomatic patients with knee osteoarthritis: preliminary results in a group of active patients. Sports Health 4(2):162-172

21. Gomoll AH, Filardo G, Almqvist FK, Bugbee WD, Jelic M, Monllau JC, Puddu G, Rodkey WG, Verdonk P, Verdonk R, Zaffagnini S, Marcacci M (2012) Surgical treatment for early osteoarthritis. Part II: allografts and concurrent procedures. Knee Surg Sports Traumatol Arthrosc 20(3):468-486

22. Gomoll AH, Filardo G, de Girolamo L, Espregueira-Mendes J, Marcacci M, Rodkey WG, Steadman JR, Zaffagnini S, Kon E (2012) Surgical treatment for early osteoarthritis. Part I: cartilage repair procedures. Knee Surg Sports Traumatol Arthrosc 20(3): 450-466

23. Gonzales VK, de Mulder EL, de Boer T, Hannink G, van Tienen TG, van Heerde WL, Buma P (2013) Platelet-rich plasma can replace fetal bovine serum in human meniscus cell cultures. Tissue Eng Part C Methods. doi:10.1089/ten.tec.2013.0009
24. Guner S, Buyukbebeci O (2012) Analyzing the effects of platelet gel on knee osteoarthritis in the rat model. Clin Appl Thromb Hemost. doi: $10.1177 / 1076029612452117$

25. Hapa O, Çakici H, Yüksel HY, Fırat T, Kükner A, Aygün H (2013) Does platelet-rich plasma enhance microfracture treatment for chronic focal chondral defects? An in vivo study performed in a rat model. Acta Orthop Traumatol Turc 47(3):201-207

26. Hart R, Safi A, Komzák M, Jajtner P, Puskeiler M, Hartová P (2013) Platelet-rich plasma in patients with tibiofemoral cartilage degeneration. Arch Orthop Trauma Surg. doi:10.1007/s00402013-1782-x

27. Heijink A, Gomoll AH, Madry H, Drobnič M, Filardo G, Espregueira-Mendes J, Van Dijk CN (2012) Biomechanical considerations in the pathogenesis of osteoarthritis of the knee. Knee Surg Sports Traumatol Arthrosc 20(3):423-435

28. Hildner F, Eder MJ, Hofer K, Aberl J, Redl H, van Griensven M, Gabriel C, Peterbauer-Scherb A (2013) Human platelet lysate successfully promotes proliferation and subsequent chondrogenic differentiation of adipose-derived stem cells: a comparison with articular chondrocytes. J Tissue Eng Regen Med. doi:10.1002/ term. 1649

29. Hunter DJ, Felson DT (2006). Osteoarthritis BMJ 18;332(7542): 639-642

30. Ishida K, Kuroda R, Miwa M, Tabata Y, Hokugo A, Kawamoto T, Sasaki K, Doita M, Kurosaka M (2007) The regenerative effects of platelet-rich plasma on meniscal cells in vitro and its in vivo application with biodegradable gelatin hydrogel. Tissue Eng 13(5):1103-1112

31. Jang SJ, Kim JD, Cha SS (2013) Platelet-rich plasma (PRP) injections as an effective treatment for early osteoarthritis. Eur J Orthop Surg Traumatol 23(5):573-580

32. Kakudo N, Minakata T, Mitsui T, Kushida S, Notodihardjo FZ, Kusumoto K (2008) Proliferation-promoting effect of plateletrich plasma on human adipose-derived stem cells and human dermal fibroblasts. Plast Reconstr Surg 122(5):1352-1360

33. Kaps C, Loch A, Haisch A, Smolian H, Burmester GR, Häupl T, Sittinger M (2002) Human platelet supernatant promotes proliferation but not differentiation of articular chondrocytes. Med Biol Eng Comput 40(4):485-490

34. Koh YG, Choi YJ (2012) Infrapatellar fat pad-derived mesenchymal stem cell therapy for knee osteoarthritis. Knee 19(6):902-907

35. Koh YG, Jo SB, Kwon OR, Suh DS, Lee SW, Park SH, Choi YJ (2013) Mesenchymal stem cell injections improve symptoms of knee osteoarthritis. Arthroscopy 29(4):748-755

36. Kon E, Buda R, Filardo G, Di Martino A, Timoncini A, Cenacchi A, Fornasari PM, Giannini S, Marcacci M (2010) Platelet-rich plasma: intra-articular knee injections produced favorable results on degenerative cartilage lesions. Knee Surg Sports Traumatol Arthrosc 18(4):472-479

37. Kon E, Filardo G, Condello V, Collarile M, Di Martino A, Zorzi C, Marcacci M (2011) Second-generation autologous chondrocyte implantation: results in patients older than 40 years. Am J Sports Med 39(8):1668-1675

38. Kon E, Filardo G, Di Martino A, Marcacci M (2011) Platelet-rich plasma (PRP) to treat sports injuries: evidence to support its use. Knee Surg Sports Traumatol Arthrosc 19(4):516-527

39. Kon E, Filardo G, Drobnic M, Madry H, Jelic M, van Dijk N, Della Villa S (2012) Non-surgical management of early knee osteoarthritis. Knee Surg Sports Traumatol Arthrosc 20(3):436-449

40. Kon E, Filardo G, Matteo BD, Marcacci M (2013) PRP for the treatment of cartilage pathology. Open Orthop J 3(7):120-128

41. Kon E, Mandelbaum B, Buda R, Filardo G, Delcogliano M, Timoncini A, Fornasari PM, Giannini S, Marcacci M (2011) Platelet-rich plasma intra-articular injection versus hyaluronicacid viscosupplementation as treatments for cartilage pathology: 
from early degeneration to osteoarthritis. Arthroscopy 27(11):1490-1501

42. Krüger JP, Hondke S, Endres M, Pruss A, Siclari A, Kaps C (2012) Human platelet-rich plasma stimulates migration and chondrogenic differentiation of human subchondral progenitor cells. J Orthop Res 30(6):845-852

43. Kwon DR, Park GY, Lee SU (2012) The effects of intra-articular platelet-rich plasma injection according to the severity of collagenase-induced knee osteoarthritis in a rabbit model. Ann Rehabil Med 36(4):458-465

44. Lee HR, Park KM, Joung YK, Park KD, Do SH (2012) Plateletrich plasma loaded hydrogel scaffold enhances chondrogenic differentiation and maturation with up-regulation of $\mathrm{CB} 1$ and CB2. J Control Release 159(3):332-337

45. Lippross S, Moeller B, Haas H, Tohidnezhad M, Steubesand N, Wruck CJ, Kurz B, Seekamp A, Pufe T, Varoga D (2011) Intraarticular injection of platelet-rich plasma reduces inflammation in a pig model of rheumatoid arthritis of the knee joint. Arthritis Rheum 63(11):3344-3353

46. Lories RJ (2008) Joint homeostasis, restoration, and remodeling in osteoarthritis. Best Pract Res Clin Rheumatol 22(2):209-220

47. Mei-Dan O, Carmont MR, Laver L, Mann G, Maffulli N, Nyska M (2012) Platelet-rich plasma or hyaluronate in the management of osteochondral lesions of the talus. Am J Sports Med 40(3):534-541

48. Mifune Y, Matsumoto T, Takayama K, Ota S, Li H, Meszaros LB, Usas A, Nagamune K, Gharaibeh B, Fu FH, Huard J (2013) The effect of platelet-rich plasma on the regenerative therapy of muscle derived stem cells for articular cartilage repair. Osteoarthritis Cartil 21(1):175-185

49. Milano G, Deriu L, Sanna Passino E, Masala G, Manunta A, Postacchini R, Saccomanno MF, Fabbriciani C (2012) Repeated platelet concentrate injections enhance reparative response of microfractures in the treatment of chondral defects of the knee: an experimental study in an animal model. Arthroscopy 28(5):688-701

50. Milano G, Deriu L, Sanna Passino E, Masala G, Saccomanno MF, Postacchini R, Fabbriciani C (2011). The effect of autologous conditioned plasma on the treatment of focal chondral defects of the knee. An experimental study. Int J Immunopathol Pharmacol 24(1 Suppl 2):117-124

51. Milano G, Sanna Passino E, Deriu L, Careddu G, Manunta L, Manunta A, Saccomanno MF, Fabbriciani C (2010) The effect of platelet rich plasma combined with microfractures on the treatment of chondral defects: an experimental study in a sheep model. Osteoarthritis Cartil 18(7):971-980

52. Mishra A, Tummala P, King A, Lee B, Kraus M, Tse V, Jacobs CR (2009) Buffered platelet-rich plasma enhances mesenchymal stem cell proliferation and chondrogenic differentiation. Tissue Eng Part C Methods 15(3):431-435

53. Moreira Teixeira LS, Leijten JC, Wennink JW, Chatterjea AG, Feijen J, van Blitterswijk CA, Dijkstra PJ, Karperien M (2012) The effect of platelet lysate supplementation of a dextran-based hydrogel on cartilage formation. Biomaterials 33(14):3651-3661

54. Muraglia A, Ottonello C, Spanò R, Dozin B, Strada P, Grandizio M, Cancedda R, Mastrogiacomo M (2013) Biological activity of a standardized freeze-dried platelet derivative to be used as cell culture medium supplement. Platelets. doi:10.3109/09537104. 2013.803529

55. Murphy MB, Blashki D, Buchanan RM, Yazdi IK, Ferrari M, Simmons PJ, Tasciotti E (2012) Adult and umbilical cord bloodderived platelet-rich plasma for mesenchymal stem cell proliferation, chemotaxis, and cryo-preservation. Biomaterials 33(21): 5308-5316

56. Napolitano M, Matera S, Bossio M, Crescibene A, Costabile E, Almolla J, Almolla H, Togo F, Giannuzzi C, Guido G (2012)
Autologous platelet gel for tissue regeneration in degenerative disorders of the knee. Blood Transfus 10(1):72-77

57. Park SI, Lee HR, Kim S, Ahn MW, Do SH (2012) Timesequential modulation in expression of growth factors from platelet-rich plasma (PRP) on the chondrocyte cultures. Mol Cell Biochem 361(1-2):9-17

58. Patel S, Dhillon MS, Aggarwal S, Marwaha N, Jain A (2013) Treatment with platelet-rich plasma is more effective than placebo for knee osteoarthritis: a prospective, double-blind, randomized trial. Am J Sports Med 41(2):356-364

59. Pereira RC, Scaranari M, Benelli R, Strada P, Reis RL, Cancedda R, Gentili C (2013) Dual effect of platelet lysate on human articular cartilage: a maintenance of chondrogenic potential and a transient proinflammatory activity followed by an inflammation resolution. Tissue Eng Part A 19(11-12):1476-1488

60. Pettersson S, Wetterö J, Tengvall P, Kratz G (2009) Human articular chondrocytes on macroporous gelatin microcarriers form structurally stable constructs with blood-derived biological glues in vitro. J Tissue Eng Regen Med 3(6):450-460

61. Saito M, Takahashi KA, Arai Y, Inoue A, Sakao K, Tonomura H, Honjo K, Nakagawa S, Inoue H, Tabata Y, Kubo T (2009) Intraarticular administration of platelet-rich plasma with biodegradable gelatin hydrogel microspheres prevents osteoarthritis progression in the rabbit knee. Clin Exp Rheumatol 27(2): 201-207

62. Sampson S, Reed M, Silvers H, Meng M, Mandelbaum B (2010) Injection of platelet-rich plasma in patients with primary and secondary knee osteoarthritis: a pilot study. Am J Phys Med Rehabil 89(12):961-969

63. Sánchez M, Anitua E, Azofra J, Aguirre JJ, Andia I (2008) Intraarticular injection of an autologous preparation rich in growth factors for the treatment of knee OA: a retrospective cohort study. Clin Exp Rheumatol 26(5):910-913

64. Sánchez M, Fiz N, Azofra J, Usabiaga J, Aduriz Recalde E, Garcia Gutierrez A, Albillos J, Gárate R, Aguirre JJ, Padilla S, Orive G, Anitua E (2012) A randomized clinical trial evaluating plasma rich in growth factors (PRGF-Endoret) versus hyaluronic acid in the short-term treatment of symptomatic knee osteoarthritis. Arthroscopy 28(8):1070-1078

65. Sánchez M, Guadilla J, Fiz N, Andia I (2012) Ultrasound-guided platelet-rich plasma injections for the treatment of osteoarthritis of the hip. Rheumatology (Oxford) 51(1):144-150

66. Serra CI, Soler C, Carillo JM, Sopena JJ, Redondo JI, Cugat R (2013) Effect of autologous platelet-rich plasma on the repair of full-thickness articular defects in rabbits. Knee Surg Sports Traumatol Arthrosc 21(8):1730-1736

67. Smyth NA, Murawski CD, Fortier LA, Cole BJ, Kennedy JG (2013) Platelet-rich plasma in the pathologic processes of cartilage: review of basic science evidence. Arthroscopy 29(8): 1399-1409

68. Spaková T, Rosocha J, Lacko M, Harvanová D, Gharaibeh A (2012) Treatment of knee joint osteoarthritis with autologous platelet-rich plasma in comparison with hyaluronic acid. Am J Phys Med Rehabil 91(5):411-417

69. Spreafico A, Chellini F, Frediani B, Bernardini G, Niccolini S, Serchi T, Collodel G, Paffetti A, Fossombroni V, Galeazzi M, Marcolongo R, Santucci A (2009) Biochemical investigation of the effects of human platelet releasates on human articular chondrocytes. J Cell Biochem 1;108(5):1153-1165

70. Torrero JI, Aroles F, Ferrer D (2012) Treatment of knee chondropathy with platelet rich plasma. Preliminary results at 6 months of follow-up with only one injection. J Biol Regul Homeost Agents 26((2 Suppl 1)):71S-78S

71. Torricelli P, Fini M, Filardo G, Tschon M, Pischedda M, Pacorini A, Kon E, Giardino R (2011) Regenerative medicine for the 
treatment of musculoskeletal overuse injuries in competition horses. Int Orthop 35(10):1569-1576

72. Tschon M, Fini M, Giardino R, Filardo G, Dallari D, Torricelli P, Martini L, Giavaresi G, Kon E, Maltarello MC, Nicolini A, Carpi A (2011) Lights and shadows concerning platelet products for musculoskeletal regeneration. Front Biosci (Elite Ed) 1(3):96-107

73. van Buul GM, Koevoet WL, Kops N, Bos PK, Verhaar JA, Weinans H, Bernsen MR, van Osch GJ (2011) Platelet-rich plasma releasate inhibits inflammatory processes in osteoarthritic chondrocytes. Am J Sports Med 39(11):2362-2370

74. Wang-Saegusa A, Cugat R, Ares O, Seijas R, Cuscó X, GarciaBalletbó M (2011) Infiltration of plasma rich in growth factors for osteoarthritis of the knee short-term effects on function and quality of life. Arch Orthop Trauma Surg 131(3):311-317

75. Wu CC, Chen WH, Zao B, Lai PL, Lin TC, Lo HY, Shieh YH, Wu CH, Deng WP (2011) Regenerative potentials of platelet-rich plasma enhanced by collagen in retrieving pro-inflammatory cytokine-inhibited chondrogenesis. Biomaterials 32(25):58475854

76. Yang SY, Ahn ST, Rhie JW, Lee KY, Choi JH, Lee BJ, Oh GT (2000) Platelet supernatant promotes proliferation of auricular chondrocytes and formation of chondrocyte mass. Ann Plast Surg 44(4):405-411

77. Yin Z, Yang X, Jiang Y, Xing L, Xu Y, Lu Y, Ding P, Ma J, Xu Y, Gui J (2013) Platelet-rich plasma combined with agarose as a bioactive scaffold to enhance cartilage repair: an in vitro study. J Biomater Appl. doi:10.1177/0885328213492573

78. Zaky SH, Ottonello A, Strada P, Cancedda R, Mastrogiacomo M (2008) Platelet lysate favours in vitro expansion of human bone marrow stromal cells for bone and cartilage engineering. J Tissue Eng Regen Med 2(8):472-481 